\title{
Why Trumpcare failed
}

\author{
Cite as: CMAJ 2017 May 1;189:E645-6. doi: 10.1503/cmaj.1095414
}

$\mathrm{U}$ nited States President Donald Trump is no fan of the Affordable Care Act, more commonly known as Obamacare. He wanted it gone, replaced by the American Health Care Act - a.k.a. Trumpcare.

His plan would be far superior to Obamacare, Trump boasted. It would be cheaper, better and provide "insurance for everybody." Obamacare "is one of the greatest threats our country faces. It is unsustainable and will lead American into complete insolvency," Trump said in one of his 435 tweets that bashed the Affordable Care Act.

In the end, however, what one pundit dubbed a "magical mystery Obamacare alternative" failed to find enough support. It was "cruel magic thinking," said another observer.

The list of critics was long, diverse and crossed political lines. Even hardcore conservative commentators expressed dismay, including Ann Coulter, who tweeted, "Who wrote this piece of crap Obamacare replacement bill?"

Facing an inevitable "stinging defeat" in the House of Representatives, Trump eventually pulled the bill, on March 25 , and the White House shifted its focus to tax reform.

So what went wrong?

One theory is that Trump and his team were never serious about repealing Obamacare in the first place. It was just politics, something he said he would do during his election campaign.

It was noted, for instance, that the efforts to repeal lasted a mere 63 days. The Affordable Care Act, on the other hand, was passed in March 2010 after more than a year of debate involving Congress and the White House.

Another problem was that the promises Trump made, both about cutting costs and about improving care, rang hollow to many Americans. Even more so after a report by the Congressional Budget Office estimated that the bill would cut $\$ 880$ billion from Medicaid over a decade, and would eventually cost 53 million Americans their health insurance, including 14 million in the first year.

One national poll found that only $17 \%$ of Americans supported Trump's bill, with
Many Americans became so concerned that they turned to activism, both online and in public. They engaged on social media. They attended town hall meetings. Some protested at Trump International Hotel and Tower in New York, carrying signs with messages such as "Trumpcare makes us sick."

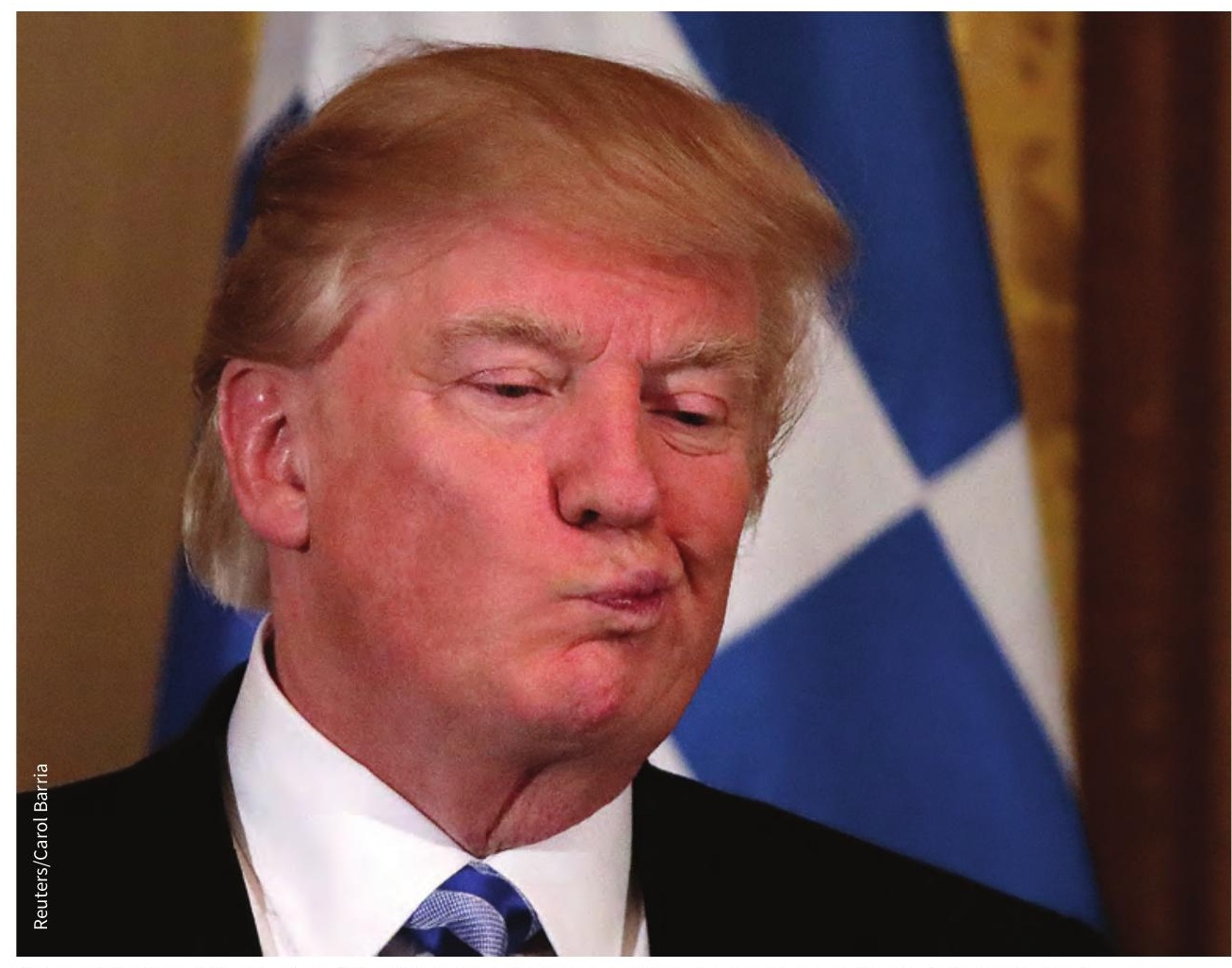

Overhauling health care for 320 million people turned out to be more complicated than US President Donald Trump had anticipated.

$56 \%$ in opposition and $26 \%$ undecided. Even among Republicans, support topped out at $24 \%$.

Critics claimed that Trump was adhering to the "free-lunch fallacy" - promising that people could pay less yet get more. Even The Wall Street Journal referred to the proposed health care bill as a "gamble," suggesting that Trump's plan basically boiled down to hoping fellow Republicans "won't dare block it."
On the political front, it may have been Trump's ego and indifference that cost him the health care battle, according to some commenters. An article in The New York Times detailing Trumpcare's demise suggested that Trump doesn't believe the regular rules of politics in Washington apply to him, and that he remains, at heart, "an image-obsessed developer with a lifelong indifference toward the mechanics of governance." 
Other political insiders have suggested that Trump appeared more interested in saving face than learning the complexities of the health care system. He feared the optics of losing and how it would affect his first-term agenda and, eventually, his chances for re-election in 2020.

He was not one to sweat the details about health care, according to one political aide, who told CNN that Trump either "doesn't know, doesn't care, or both."
Indeed, according to Politico, the president is not one to pay too much attention to day-to-day operations, leaving that up to those below him.

"Trump is a business executive. When he tells his lieutenants to get something done, he's used to it getting done," one senior Republican aide told Politico. "He's really not used to getting involved himself."

Even Trump admitted that the challenge of transforming health care was big- ger than he had imagined, saying in late February, "Nobody knew that health care could be so complicated".

Later, when asked about this statement Vermont Senator Bernie Sanders, who also aspired to be president, broke into laughter. "When you provide health care in a nation of 320 million people, yeah, it is very, very complicated," he said.

Roger Collier, CMAJ 